\title{
ANALISIS MULTIDIMENSIONAL SCALING UNTUK PEMETAAN APLIKASI PEMBELAJARAN DARING
}

\author{
Nur Baiti Nasution, Padrul Jana \\ ${ }^{1}$ Pendidikan Matematika, Universitas Pekalongan \\ Email: nurbaiti.nasution@unikal.ac.id \\ ${ }^{2}$ Pendidikan Matematika, Universitas PGRI Yogyakarta \\ Email: padrul.jana@upy.ac.id
}

\begin{abstract}
Due to Covid-19 pandemic, many schools and universities in Indonesia are forced to implement online learning since March 2020. After implementing for 2 semester, teachers and lecturers are considered to be more experienced in online learning. Therefore, they must have certain opinion about the similarity of online learning platforms which they have been using. This sudy aimed to find a perceptual map from teachers and lecturers to 7 online learning platform known in Indonesia. The platforms are Whatsapp, Telegram, Google Classroom, Schoology, Teams, LMS Moodle, and Edmodo. This was an explorative and descriptive study using non attribute multidimensional scaling. There were 30 respondents who were willing to give their opinion about the similarity of the platforms. The results showed that the perceptual map consists of 3 different groups. The first group consists of Telegram and Whatsapp, the second group consists of Moodle, Schoology, and Edmodo, and the third group consists of Google Classroom and Teams. The validity of this results is shown by the stress value which is $4.98 \%$ and the $R^{2}$ which is 0.993 . This means that the result is categorized to be very good.
\end{abstract}

Keywords: multidimensional scaling, online learning platform, perceptual map.

\begin{abstract}
ABSTRAK
Sejak Covid 19 ditetapkan sebagai pandemi bulan Maret 2020 lalu, sebagian besar sekolah dan perguruan tinggi di Indonesia mulai menerapkan pembelajaran daring. Setelah berjalan selama 2 semester, baik guru dan dosen telah memiliki pengalaman yang cukup dalam mengelola kelas secara daring. Dengan kata lain, setiap guru atau dosen pastilah telah memiliki pendapat mengenai kemiripan setiap pasangan aplikasi pembelajaran daring. Penelitian ini bertujuan untuk memetakan posisi dari 7 aplikasi yang sering digunakan sebagai platform pembelajaran daring dalam suatu ruang multidimensi berdasarkan pendapat responden mengenai kemiripan ketujuh aplikasi tersebut. Ketujuh aplikasi tersebut adalah Whatsapp, Telegram, Google Classroom, Schoology, Teams, LMS Moodle, dan Edmodo. Hasil akhir dari penelitian ini adalah suatu peta spasial yang menggambarkan kemiripan tujuh aplikasi tersebut. Penelitian ini bersifat deskriptif eksploratif dengan menggunakan multidimensional scaling non atribut sebagai metode analisis data. Terdapat 30 responden yang bersedia berpartisipasi dengan memberikan pendapat mengenai seberapa mirip masingmasing platform. Hasil analisis menunjukkan bahwa dalam peta spasial yang terbentuk terdapat 3 kelompok yang muncul, yaitu kelompok 1 terdiri atas Telegram dan Whatsapp, kelompok 2 terdiri atas Moodle, Schoology, dan Edmodo, dan kelompok 3 berisikan Google Classroom dan Teams. Hasil MDS ini memiliki tingkat stress sebesar 4,98\% dan nilai $\mathrm{R}^{2}$
\end{abstract}


sebesar 0.993 yang berarti hasil MDS dinilai sangat baik.

Kata kunci: aplikasi e-learning, multidimensional scaling, peta spasial.

\section{PENDAHULUAN}

Pandemi Covid-19 yang menyebar di seluruh dunia pada awal tahun 2020 telah mengubah banyak tatanan hidup manusia, salah satunya di bidang pendidikan. Karena wabah penyakit tersebut, setiap orang dilarang untuk berinteraksi fisik dalam jarak dekat dengan orang lain, untuk menghindari resiko tertular penyakit. Hal ini mengakibatkan kegiatan belajar mengajar di sekolah dan universitas pun dibatasi dan sistem pembelajaran diubah menjadi sistem pembelajaran daring. Guru dan dosen pun dituntut untuk menjadi mahir dalam menggunakan berbagai aplikasi pembelajaran daring.

Implementasi pembelajaran daring di Indonesia karena pandemi Covid 19 dimulai pada bulan Maret 2020, tepatnya pada pertengahan semester genap tahun ajaran 2019/2020. Pada masa itu, guru atau dosen, umumnya, masih gagap dalam memanfaatkan berbagai aplikasi pembelajaran daring dan masih mencari pola dalam menerapkan sistem pembelajaran daring (Ariadhy, Shulby Yozar., Nurohman, Sabar., Arkum, Darol., Handini, Widya., 2020; Asmuni, 2020). Seiring dengan berjalannya waktu, pada awal semester ganjil tahun ajaran 2020/2021, guru lebih siap dalam menghadapi pembelajaran daring. Hal ini ditunjukkan dengan munculnya berbagai publikasi mengenai keberhasilan pembelajaran daring pada rentang waktu tersebut (Amalia \& Fatonah, 2020; Widiyono, 2020) dan juga banyaknya kegiatan pelatihan mengenai pembelajaran daring di era pandemi yang diselenggarakan oleh berbagai institusi (Ariadhy, Shulby Yozar., Nurohman, Sabar., Arkum, Darol., Handini, Widya., 2020; Busa, 2020).

Seiring dengan semakin mahirnya guru dan dosen mengimplementasikan pembelajaran daring, pendapat mengenai berbagai aplikasi pembelajaran daring akan semakin jelas, khususnya pendapat mengenai aplikasi pembelajaran daring mana saja yang penggunaannya dianggap mirip (similar). Tingkat kemiripan (similarity) sendiri dapat digunakan untuk menggambar suatu diagram yang menunjukkan posisi masingmasing aplikasi sesuai dengan pendapat responden (Janssens, W., De Pelsmacker, P., Wijnen, K., \& Van Kenhove, 2008). Semakin besar tingkat kemiripannya maka semakin dekat kedudukannya dalam diagram tersebut. Diagram tersebut disebut dengan peta spasial. Hingga saat ini, belum ada studi berusaha memetakan berbagai aplikasi 
pembelajaran daring ke dalam suatu peta spasial.

Teknik analisis data yang digunakan untuk membangun suatu peta spasial berdasarkan pendapat responden adalah analisis multidimensional scaling dan analisis korespondensi (Kim \& Agrusa, 2005; Wen \& Yeh, 2010). Studi ini menggunakan analisis multidimensional scaling. Analisis ini merupakan salah satu teknik analisis yang digunakan untuk memperoleh peta spasial yang menggambarkan tingkat kemiripan beberapa objek. Terdapat 2 jenis multidimensional scaling (MDS) yaitu MDS tanpa atribut dan MDS dengan atribut. MDS tanpa atribut adalah teknik MDS dimana data yang digunakan adalah data mengenai kemiripan 2 objek tanpa diketahui atribut yang menjadi pertimbangan utama kemiripannya. Sedangkan MDS dengan atribut adalah MDS dimana responden diminta menentukan kemiripan objek-objek menggunakan pertimbangan/atribut yang ditentukan oleh peneliti.

Pada penelitian ini diterapkan MDS tanpa atribut untuk menganalisis tingkat kemiripan 7 platform e-learning, yaitu Whatsapp, Telegram, Google Classroom, Schoology, Microsoft Teams, LMS Moodle, dan Edmodo. Aplikasi Whatsapp sejatinya bukanlah merupakan platform pembelajaran daring, akan tetapi, aplikasi tersebut memiliki fasilitas grup yang pada akhirnya digunakan sebagai salah satu alternatif pembelajaran daring (Mulyana et al., 2020; Widiyono, 2020). Hal yang sama juga berlaku untuk Telegram. Khususnya pada aplikasi Telegram, minimnya memori yang diperlukan dan adanya fasilitas pembuatan bot pembelajaran menjadi pertimbangan utama dalam menggunakannya (Rosali et al., 2020; Setiaji \& Paputungan, 2018).

Adapun LMS yang dipilih untuk diteliti adalah Google Classroom, Edmodo, Moodle dan Schoology. Google Classroom dan Teams dinilai mudah diterima dan memberikan efek yang positif bagi pembelajaran di kelas (Batita et al., 2019; Pradja \& Baist, 2019; Situmorang, 2020). Sedangkan Edmodo dinilai memiliki fitur yang mudah dan menyenangkan (Retnoningsih, 2017). Yang terakhir, Schoology dipilih dalam penelitian karena dinilai memiliki kelebihan dalam memberikan suasana pembelajaran yang interaktif dan menstimulus motivasi belajar siswa (Tigowati et al., 2017).

Artikel ini bertujuan untuk mengetahui bagaimana pemetaan posisi berbagai aplikasi tersebut berdasarkan pendapat guru dan dosen. Hasil akhir dari teknik ini berupa tampilan peta atau gambar dua dimensi yang menunjukkan posisi relatif suatu objek dengan objek lainnya (Pura et al., 2019). 


\section{METODOLOGI}

Penelitian ini merupakan penelitian deskriptif dan eksploratif. Penelitian deskriptif merupakan jenis penelitian dimana proses generalisasi hasil analisis ke tingkat populasi tidak dilakukan. Hasil akhir penelitian ini hanya berlaku untuk sampel saja tidak berlaku untuk keseluruhan guru atau dosen yang menjadi populasi. Sedangkan penelitian eksploratif adalah penelitian yang bertujuan menghimpun informasi awal yang akan membantu upaya menetapkan masalah dan merumuskan hipotesis untuk penelitian lanjutan (Herman, 2010). Analisis data pada penelitian ini menggunakan teknik MDS tanpa atribut, yang mana teknik tersebut hanya menghasilkan peta spasial yang menggambarkan tingkat kemiripan antara setiap objek yang diteliti tanpa diketahui kriteria atau atribut yang mendasari penilaiannya. Akibatnya, setelah penelitian ini berakhir akan muncul pertanyaan baru mengenai atribut apa saja yang mendasari responden dalam mengatakan bahwa platform A dan B dianggap mirip.

Kriteria utama yang digunakan dalam memilih responden adalah tingkat pengetahuan mereka mengenai berbagai platform pembelajaran daring. Responden yang ideal adalah responden yang pernah mengenal ketujuh platform tersebut. Pengumpulan data dilakukan menggunakan Google Form yang terdiri dari 2 bagian. Bagian yang pertama digunakan untuk menanyakan mengenai identitas responden. Bagian yang kedua adalah bagian yang digunakan untuk menilai kemiripan setiap pasangan platform dari 7 platform/aplikasi yang diteliti. Dengan demikian, terdapat $C_{2}^{7}=21$ pasangan platform. Untuk setiap pasangan, responden diminta untuk menilai kemiripannya dengan skala Likert dari 1 hingga 5 dengan 1 menunjukkan sangat mirip dan 5 menunjukkan sangat tidak mirip. Responden dapat menggunakan kriteria apa saja yang ada dalam benak mereka untuk menentukan tingkat kemiripannya (Janssens, W., De Pelsmacker, P., Wijnen, K., \& Van Kenhove, 2008). Form kemudian disebar di berbagai grup Whatsapp, Telegram, dan Facebook yang memuat dosen dan guru-guru. Selain itu, form juga dikirimkan ke dosen atau guru yang diketahui memiliki pengetahuan lebih mengenai berbagai platform pembelajaran daring. Pengumpulan data dilakukan selama 7 hari yaitu di minggu kedua bulan Desember 2020. Terdapat 30 responden yang bersedia mengisi instrumen pengumpulan data.

Tahap selanjutnya adalah melakukan analisis MDS non atribut menggunakan 
software SPSS 22. Urutan langkah-langkah yang dilakukan pada tahap ini adalah :

a. Menghitung nilai rata-rata penilaian responden untuk setiap pasangan platform

b. Menghitung jarak kemiripan antar masing-masing platform menggunakan rumus Euclidean

c. Menghitung koordinat masing-masing platform dan menempatkannya dalam peta spasial berdimensi 2 .

d. Menghitung nilai stress dan $\mathrm{R}^{2}$ dari hasil analisis sebagai wujud kevalidan hasil analisis.

Kriteria nilai stress ditunjukkan pada Tabel 1.

\section{Tabel 1 Kriteria Nilai Stress}

\begin{tabular}{|c|c|}
\hline Nilai Stress & Kriteria \\
\hline$>20 \%$ & Buruk \\
\hline $10 \%-20 \%$ & Cukup \\
\hline $5,1 \%-10 \%$ & Baik \\
\hline $2,5 \%-5 \%$ & Sangat Baik \\
\hline$<2,5 \%$ & Sempurna \\
\hline
\end{tabular}

(Janssens, W., De Pelsmacker, P., Wijnen, K., \& Van Kenhove, 2008)

Sedangkan untuk nilai $\mathrm{R}^{2}$, hasil MDS dinyatakan dapat diterima jika nilai $\mathrm{R}^{2}>0.6$ (Nafisah \& Setiawan, 2019).

\section{HASIL DAN PEMBAHASAN}

\subsection{Profil Responden}

Terdapat sebanyak 30 guru dan dosen yang bersedia mengisi form. Sebagian besar dari responden berasal dari Jawa Tengah yaitu Kota dan Kabupaten Pekalongan, Kota Solo, Kota Kudus, Kota Kebumen, Kota Semarang, dan Purworejo. Selain itu, terdapat 5 responden dari luar Jawa Tengah yaitu dari Kota Yogyakarta, Kota Surabaya, Kota Pontianak, Kota Tasikmalaya, dan dari Provinsi Nangroe Aceh Darusalam.

Dari 30 responden tersebut, diketahui bahwa 28 orang di antaranya adalah dosen dan 2 orang di antaranya adalah guru. Hal ini penting untuk diketahui mengingat kebijakan sekolah dan universitas selama masa pandemi berbeda-beda. Akan tetapi, kebijakan di sekolah satu biasanya juga diikuti di sekolah lain. Oleh sebab itu, faktor institusi asal responden merupakan atribut yang perlu diperhatikan. 


\subsection{Hasil Multidimensional Scaling}

Selanjutnya, dilakukan penghitungan rata-rata nilai kemiripan untuk setiap pasangan. Kriteria yang digunakan adalah jika responden menganggap 2 platform semakin mirip maka nilai yang diberikan semakin mendekati 1 , dan sebaliknya, jika kedua platform dianggap semakin tidak mirip maka nilai akan semakin mendekati 5 . Hasil perhitungan tersebut ditunjukkan pada Tabel 2.

Tabel 2 Rata-Rata Nilai Kemiripan Masing-Masing Pasangan Platform

\begin{tabular}{lccccccc}
\hline & WA & Telegram & Classroom & Schoology & Teams & Moodle & Edmodo \\
\hline WA & 0 & 1.74 & 2.63 & 2.72 & 2.59 & 2.59 & 2.67 \\
Telegram & 1.74 & 0 & 2.60 & 2.57 & 2.53 & 2.53 & 2.60 \\
Classroom & 2.63 & 2.60 & 0 & 1.67 & 1.50 & 1.72 & 1.67 \\
Schoology & 2.72 & 2.57 & 1.67 & 0 & 1.83 & 1.63 & 1.57 \\
Teams & 2.59 & 2.53 & 1.50 & 1.83 & 0 & 1.67 & 1.70 \\
Moodle & 2.59 & 2.53 & 1.72 & 1.63 & 1.67 & 0 & 1.60 \\
Edmodo & 2.67 & 2.60 & 1.67 & 1.57 & 1.70 & 1.60 & 0 \\
\hline
\end{tabular}

Pada Tabel 2 dapat dilihat bahwa rata-rata nilai kemiripan antara aplikasi Whatsapp dengan Telegram adalah 1.74. Hal ini menunjukkan bahwa responden menganggap bahwa aplikasi Whatsapp dan Telegram cenderung mirip. Sedangkan, ratarata nilai kemiripan yang diberikan untuk aplikasi Whatsapp dan Schoology adalah 2.72. Hal ini berarti responden menganggap bahwa Schoology tidak terlalu mirip dengan Whatsapp. Nilai 0 pada Tabel 2 menunjukkan bahwa kedua aplikasi yang bersesuaian dengan sel tersebut dapat dianggap identik. Hal ini masuk akal karena nilai nol hanya muncul pada sel-sel yang mana pasangan aplikasi yang dibandingkan adalah aplikasi yang sama.

Setelah melakukan penghitungan rata-rata nilai kemiripan antar platform, dilakukan penghitungan jarak antar setiap platform menggunakan rumus jarak Euclidian. Selanjutnya ditentukan koordinat masing-masing platform dalam suatu bidang koordinat 2 dimensi sehingga dapat ditentukan peta spasial dari data. Adapun peta spasial yang terbentuk ditunjukkan pada Gambar 1. 


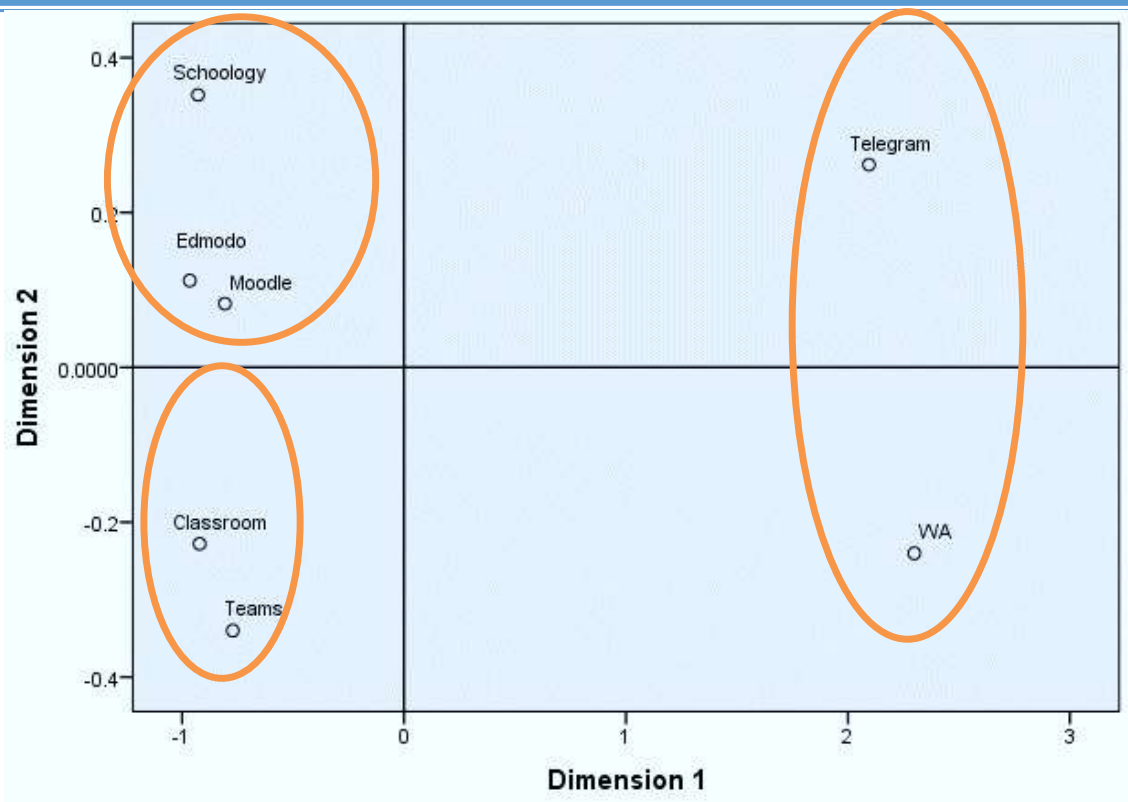

\section{Gambar 1 Peta Spasial Yang Menggambarkan Pendapat Responden}

Pada Gambar 1 tampak bahwa terdapat 3 kelompok yang terbentuk. Kelompok 1 berisikan Google Classroom dan Teams, Kelompok 2 berisikan Edmodo, Moodle, dan Schoology, dan Kelompok 3 berisikan Telegram dan Whatsapp. Walau demikian, hasil multidimensional scaling non atribut ini belum menjawab mengenai apa pertimbangan yang paling dominan yang digunakan responden untuk menilai kemiripan antara setiap 2 platform pembelajaran daring. Hal ini dapat dijadikan pertanyaan untuk penelitian selanjutnya.

Langkah terakhir pada analisis multidimensional scaling adalah menghitung tingkat validitas analisis dengan menghitung nilai stress dan $\mathrm{R}^{2}$. Hasil perhitungan menggunakan software SPSS 22 menunjukkan bahwa nilai stress yang dihasilkan adalah sebesar 4,98\%. Dengan demikian, menurut Tabel 1, nilai stress tersebut menunjukkan kategori Sangat Baik. Nilai stress tersebut menunjukkan bahwa peta yang terbentuk dapat menggambarkan sebanyak 95,02 \% data. Hal yang sama juga diungkapkan oleh nilai $\mathrm{R}^{2}$ yaitu sebesar 0,993 atau $99,3 \%$. Nilai ini menunjukkan bahwa hasil analisis telah sesuai dengan sebanyak $99,3 \%$ data.

\subsection{Pembahasan}

Pada MDS non atribut, tidak dapat ditentukan pertimbangan apa yang digunakan responden dalam menentukan tingkat kemiripan sepasang objek. Yang dapat dlilakukan hanyalah membuat dugaan mengenai dimensi apa yang digunakan untuk melakukan 
penilaian sesuai dengan peta persepsi yang terbentuk selanjutnya melakukan penelitian yang sama menggunakan pendekatan atribut (Herman, 2010) atau dengan analisis data lain seperti analisis korespondensi (Kim \& Agrusa, 2005). Oleh sebab itu, pada bagian ini hanya akan dibahas mengenai tingkat kemiripan platform yang letaknya berdekatan. Tingkat kemiripan tersebut dapat dilihat dari kedekatan jaraknya, letaknya dalam satu kuadran, atau letaknya pada setiap dimensi/sumbu koordinat.

Dari Gambar 1 tampak bahwa platform Google Classroom dianggap mirip dengan Teams karena terletak berdekatan dan pada kuadran yang sama. Hal yang sama juga terjadi pada Edmodo, Moodle, dan Schoology yang terletak pada kuadran yang sama dan berdekatan Untuk aplikasi Telegram dan WA, meskipun tidak berdekatan dan tidak terletak pada kuadran yang sama, kedua aplikasi tersebut dapat dianggap mirip jika hanya dilihat dari koordinat kedua aplikasi tersebut pada dimensi 1. Hal ini diperkuat dengan nilai kemiripan yang dimiliki oleh Telegram dan WA yaitu 1,74. Nilai ini mendekati nilai kemiripan yang dimiliki Google Classroom dan Teams yaitu 1,50.

Jika dilihat hanya dari dimensi 1, Telegram hanya berdekatan dengan WA dan aplikasi yang lain saling berdekatan. Dalam hal ini dapat dikatakan bahwa kemungkinan dimensi 1 merupakan dimensi yang mempertimbangkan bahwa aplikasi Telegram dan WA bukanlah sebuah platform pembelajaran daring merupakan hanyalah aplikasi pesan yang memiliki fitur grup yang dapat digunakan sebagai kelas online. Pada Telegram dan WA juga tidak ada fitur administrasi kelas dan administrasi penilaian seperti halnya aplikasi pembelajaran daring yang lain

Selanjutnya dari sudut pandang dimensi 2, Teams berdekatan dengan Google Classroom dan Edmodo berdekatan dengan Moodle. Adapun Schoology meskipun cukup terasing tetapi masih berada di kuadran yang sama dengan Edmodo dan Moodle. Melihat hasil ini, dapat disimpulkan bahwa responden menganggap bahwa Google Classroom dan Teams merupakan platform pembelajaran daring yang mirip. Hal ini cukup masuk akal mengingat kedua platform tersebut merupakan platform yang paling sering digunakan. Google Classroom cukup dikenal karena kemudahannya dalam membuat akun (Batita et al., 2019). Sedangkan Teams cukup dikenal karena semenjak pandemi, banyak sekolah dan institusi yang mengadakan pelatihan Microsoft 365 dimana Teams merupakan salah satu aplikasi yang ditawarkan. Selain itu. Teams juga telah terbukti mudah diakses dan membawa efek positif ke output pembelajaran (Pradja \& Baist, 2019; Situmorang, 2020). 
Platform Edmodo, Moodle, dan Schoology memiliki kesamaan dalam hal kelengkapan fitur dalam pembelajaran. Hal ini sesuai dengan pendapat dari penelitian terdahulu yang menyatakan bahwa Moodle, Edmodo, dan Schoology memberikan efek yang positif dalam pembelajaran meliputi peningkatan minat, motivasi, dan prestasi belajar dikarenakan kelengkapan fitur yang ada (Batita et al., 2019; Retnoningsih, 2017; Tigowati et al., 2017). Walau demikian, semenjak pandemi, pengguna Schoology perlu membayar sejumlah tarif untuk tetap menggunakan layanannya. Di sisi lain, untuk Moodle, pengguna perlu membuat domain website sendiri untuk dapat menggunakan Moodle. Hal ini belum tentu dapat diikuti oleh setiap instansi pendidikan. Dengan demikian, Moodle dan Schoology tidak memiliki pengguna sebanyak Google Classroom dan Teams. Hal ini menyebabkan tingkat kemiripan Moodle dan Schoology tinggi dan terletak saling berdekatan. Analog dengan kondisi pada Moodle, aplikasi Telegram dan WA yang terletak saling berjauhan. Aplikasi WA berdekatan dengan Google Classroom dan Teams yang berarti telah dikenal masyarakat secara luas dan Telegram berdekatan dengan aplikasi lainnya yang belum banyak digunakan oleh pengajar.

\section{SIMPULAN}

Kesimpulan dari hasil penelitian ini adalah :

a. Hasil multidimensional scaling menunjukkan bahwa terdapat 3 kelompok platform pembelajaran daring dimana anggota masing-masing kelompok dianggap mirip oleh responden. Kelompok 1 terdiri dari Google Classroom dan Teams, Kelompok 2 terdiri dari Edmodo, Moodle, dan Schoology, dan Kelompok 3 terdiri dari Telegram dan Whatsapp.

b. Hasil MDS ini memiliki tingkat stress sebesar 4,98\% dan nilai $\mathrm{R}^{2}$ sebesar 0,993 yang berarti hasil MDS dinilai sangat baik.

Saran untuk penelitian lanjutan yang dapat dilakukan adalah penelitian sejenis menggunakan atribut tertentu atau menggunakan analisis data multivariat lain yang juga membangun peta persepsi seperti analisis korespondensi.

\section{DAFTAR PUSTAKA}

Amalia, A., \& Fatonah, S. (2020). Penerapan Pembelajaran Daring Dragonlearn pada Era Pandemic Covid-19 (Studi Kasus di MI Ma'had Islam Kopeng). ISEJ: Indonesian Science Education

Journal,

$1(3)$, 148-164. 
https://siducat.org/index.php/isej/article/view/81

Ariadhy, Shulby Yozar., Nurohman, Sabar., Arkum, Darol., Handini, Widya., F. (2020).

Permasalahan Pembelajaran Jarak Jauh Di Era Pandemi. Pusat Penelitian Badan Keahlian DPR R, 13-18. https://berkas.dpr.go.id/puslit/files/info_singkat/Info SingkatXII-12-II-P3DI-Juni-2020-201.pdf

Asmuni, A. (2020). Problematika Pembelajaran Daring di Masa Pandemi Covid-19 dan $\begin{array}{lllll}\text { Solusi Pemecahannya. Jurnal Paedagogy, } & \text { 7(4), } 281 .\end{array}$ https://doi.org/10.33394/jp.v7i4.2941

Batita, M. S. R., Wijoyo, S. H., Herlambang, A. D., \& Maurish Sofie Rahmi Batita, Satrio Hadi Wijoyo, A. D. H. (2019). Analisis Perbandingan Blended Learning berbasis Edmodo dan Google Classroom ditinjau dari Motivasi dan Hasil Belajar Siswa. Jurnal Pengembangan Teknologi Informasi Dan Ilmu Komputer, 3(4), 3756-3764. http://jptiik.ub.ac.id

Busa, Y. (2020). Bimbingan Teknis Pembuatan Media Pembelajaran Digital secara daring oleh civitas akademika ditengah pandemi Covid-19. CARADDE: Jurnal Pengabdian Kepada Masyarakat, 3(1), 158-165.

Herman, R. T. (2010). PENERAPAN MODEL MULTIDIMENSIONAL SCALING Robertus Tang Herman. Journal The WINNERS, 11(1), 81-93.

Janssens, W., De Pelsmacker, P., Wijnen, K., \& Van Kenhove, P. (2008). Marketing Research With SPSS. Pearson Education Inc.

Kim, S. S., \& Agrusa, J. (2005). The positioning of overseas honeymoon destinations. Annals of Tourism Research, 32(4), 887-904. https://doi.org/10.1016/j.annals.2004.12.004

Mulyana, M., Rainanto, B. H., Astrini, D., \& Puspitasari, R. (2020). Persepsi Mahasiswa Atas Penggunaan Aplikasi Perkuliahan Daring Saat Wabah Covid-19. JAS-PT (Jurnal Analisis Sistem Pendidikan Tinggi Indonesia), 4(1), 47. https://doi.org/10.36339/jaspt.v4i1.301

Nafisah, S., \& Setiawan, T. H. (2019). Penerapan Analisis Multidimensional Scaling Pada Pemetaan Karakteristik Kemiskinan Di Provinsi Banten. Statmat : Jurnal Statistika Dan Matematika, 1(2), 46-59. https://doi.org/10.32493/sm.v1i2.2946

Pradja, B. P., \& Baist, A. (2019). Analisis kualitatif penggunaan Microsoft Teams dalam pembelajaran kolaboratif daring. Seminar Nasional Matematika Dan Pendidikan Matematika

Senatik), $415-420$ 
http://103.98.176.39/index.php/senatik/article/view/88

Pura, M., Nainggolan, N., \& Komalig, H. (2019). Analisis Multidimensional Scaling Untuk Jarak Antara Fakultas-fakultas serta Program Pasca Sarjana di Universitas Sam Ratulangi Manado. d'CartesiaN Jurnal Matematika dan Aplikasi, 8(1), 65-68.

Retnoningsih, E. (2017). Perbandingan Learning Management System Edmodo dan Moodle Dalam Pembelajaran Online. Information System for Educators and Professionals, 1(2), 221-230. www.edmodo.com

Situmorang, A. S. (2020). Microsoft Teams for Education Sebagai Media Pembelajaran. Microsoft Teams for Education Sebagai Media Pembelajaran Interaktif Meningkatkan Minat Belajar, 02(01), 30-35.

Tigowati, T., Efendi, A., \& Budiyanto, C. W. (2017). E-Learning Berbasis Schoology Dan Edmodo: Ditinjau Dari Motivasi Dan Hasil Belajar Siswa Smk. Elinvo (Electronics, $\begin{array}{llll}\text { Informatics, } \quad \text { and } \quad \text { Vocational } & \text { 2(1), }\end{array}$ https://doi.org/10.21831/elinvo.v2i1.16416

Wen, C. H., \& Yeh, W. Y. A. (2010). Positioning of international air passenger carriers using multidimensional scaling and correspondence analysis. Transportation Journal, 49(1), $7-23$.

Widiyono, A. (2020). Efektifitas Perkuliahan Daring (Online) pada Mahasiswa PGSD di Saat Pandemi Covid 19. Jurnal Pendidikan, 8(2), 169-177. https://doi.org/10.36232/pendidikan.v8i2.458 